\title{
El Métraux haitiano. La construcción de una etnología religiosa
}

The Haitian Métraux. The construction of a religious anthropology

Le Métraux haïtien. La construction d'une ethnologie religieuse

\section{Fernando Giobellina Brumana}

\section{(2) OpenEdition}

Journals

\section{Edición electrónica}

URL: https://journals.openedition.org/jsa/14798

DOI: $10.4000 / j s a .14798$

ISSN: $1957-7842$

Editor

Société des américanistes

Edición impresa

Fecha de publicación: 31 diciembre 2016

Paginación: 145-167

ISSN: 0037-9174

Referencia electrónica

Fernando Giobellina Brumana, «El Métraux haitiano. La construcción de una etnología religiosa», Journal de la Société des américanistes [En línea], 102-2 | 2016, Publicado el 26 enero 2017, consultado el 04 septiembre 2022. URL: http://journals.openedition.org/jsa/14798 ; DOl: https://doi.org/10.4000/ jsa. 14798 


\title{
El Métraux haitiano. La construcción de una etnología religiosa
}

\author{
Fernando Giobellina Brumana *
}

Este trabajo destaca las novedades teóricas y metodológicas de Le vaudou haïtien, así como su originalidad en el abordaje de los cultos americanos de raíces africanas. El libro de Métraux nos brinda varias innovaciones teóricas y metodológicas claves: 1. la búsqueda de una suerte de sintaxis ritual; 2. el ir por detrás de las formulaciones letradas del culto para centrarse en las prácticas reales; 3 . el reconocimiento de que el vudú es inconfundiblemente haitiano y de que sus raíces son tanto europeas como africanas; 4. el rechazo a que el catolicismo de los vuduistas fuese una mera artimaña, y 5. la revelación y registro de un plano narrativo que sustituye el relato de los avatares de los dioses por el de su influencia en la vida de los humanos. Al mismo tiempo aquí se exploran las relaciones de Alfred Métraux con algunos de los investigadores que lo precedieron, o que coincidieron con él, en el estudio del vudú, así como también con los intermediarios que facilitaron su investigación. [Palabras clave: Haití, Métraux, Vudú.]

The Haitian Métraux. The construction of a religious anthropology. This paper highlights the theoretical and methodological innovations of Le vaudou haïtien, and its originality for the study of cults of African origin in the Americas. Métraux achieves several key theoretical and methodological innovations in this book: 1. the search for a kind of ritual syntax; 2. a focus on real practices instead of lettered formations of the cult; 3 . an acknowledgement that voodoo is unmistakably Haitian and that its roots are European as much as African; 4. a rejection of the assumption that the Catholicism of voodoo adepts would be mere deception; 5. the identification of a narrative level where stories of the gods' avatars are replaced by tales of their interventions in the life of humans. At the same time, it explores Alfred Métraux's relationships with some scholars that preceded him on the matter, with researchers that studied voodoo as well, and with the intermediaries that facilitated his investigation. [Key words: Haiti, Métraux, Voodoo.]

Le Métraux haïtien. La construction d'une ethnologie religieuse. Ce travail souligne les nouveautés théoriques et méthodologiques de Le vaudou haïtien, de même que

* Universidad de Cádiz [fernando.giobellina@uca.es]. 
son originalité dans la manière d'aborder des cultes d'origine africaine dans les Amériques. Métraux effectue plusieurs innovations théoriques et méthodologiques clés dans cet ouvrage: 1 . rechercher une sorte de syntaxe rituelle; 2 . contourner des formulations savantes du culte pour se centrer sur les pratiques réelles; 3 . reconnaître que le vaudou est incontestablement haïtien et que ses racines sont européennes autant qu'africaines; 4. rejeter l'idée que le catholicisme des adeptes du vaudou serait un pur artifice; 5. identifier un niveau narratif où l'histoire des avatars des dieux est remplacé par celle de leurs interventions dans la vie des hommes. L'article explore également les relations d'Alfred Métraux avec quelques-uns de ses prédécesseurs ou contemporains dans l'étude du Vaudou, et avec les intermédiaires qui facilitèrent ses recherches. [Mots-clés: Haiti, Métraux, Vaudou.]

El propósito de este texto es abordar la producción sobre el vudú que Alfred Métraux llevó a cabo a partir de sus sucesivos viajes a Haití (1941, 1944, 1947). En la última etapa coincidió su labor de investigador con la de funcionario de la UNESCO a cargo de un programa de desarrollo; ya veremos el malestar que le provocaba esa doble función, que le parecía incompatible. La pieza principal del estudio sobre el culto es Le vaudou haïtien, libro que, casi sesenta años después de su publicación, es un referente no ya para los estudiosos del vudú, sino para quienes quieran dar cuenta de cualquier otro culto, un ejemplo para la etnología religiosa: para la etnología sin más. Las líneas que siguen apuntan a ofrecer algunos elementos que permitan captar el arte con que el autor vuelve patente la realidad del objeto de estudio, las innovaciones que en ese empeño articula, así como su empleo de los trabajos que le precedieron, la forma concreta con que desarrolló su investigación, y los problemas en que pudo verse envuelto. El texto no quiere ser tanto una aproximación histórica a un estadio pasado de la disciplina, sino más bien un diálogo con una obra abierta, aún fructífera.

\section{La labor de Métraux}

Lo primero que salta a la vista en Le vaudou haïtien es su intención de totalidad, es decir, el propósito de barrer sistemáticamente todos los aspectos del fenómeno en un recorrido diseñado para permitir el tránsito más esclarecedor posible, que, tras introducirse históricamente en la cuestión, parte de la organización y de la topología material y simbólica de la agencia vuduista, continúa con el complejo mundo espiritual de los loa (entidades místicas) a los que en las agencias se rinde culto, para desembocar finalmente en las acciones rituales por las que el culto se lleva a cabo, desde las formas legítimas hasta las ilegítimas de la hechicería. Por último, Métraux proporciona una visión del vudú y de los vuduistas dentro del campo religioso haitiano: la relación ambivalente que mantenían con el catolicismo y cómo su situación de blanco de los ataques de las diversas denominaciones protestantes no paraba de empeorar. 
Para un cometido tal, echa mano a su propia etnografía, con el buen juicio de mantener la descripción de las ceremonias registradas en un grado que no abrume al lector con una masa excesiva de detalles; también incorpora la literatura existente allí donde ésta mostraba informaciones que él no había obtenido por sí mismo. La actitud con que abordaba esta obra de síntesis era, dice Métraux (1958, p. 12), el método y la prudencia, alejado

del entusiasmo de quienes en contacto con una religión exótica son tomados por una especie de vértigo sagrado y terminan por compartir la credulidad de sus adeptos, también me he esforzado por evitar la actitud de esos voltairianos domingueros que no paran de hablar de fraude con guiños de entendido.

Ni devota abducción - ¿como la de su amigo Verger? - ni ironía displicente, otros son los resortes que mueven a Métraux. En Haití, como testigo de la severa campaña eclesiástica que con apoyo gubernamental había sido desencadenada contra el vudú ${ }^{1}$, siente que algo muy importante está al borde de la desaparición y que había que dejar memoria de ese patrimonio espiritual. Debía, pues, ser practicada una antropología de rescate, pero no a la manera en que lo había hecho con los indios chaqueños, con quienes la urgencia surgía de una amenaza casi apocalíptica.

En el caso haitiano, pensaba Métraux, había una pérdida más o menos inminente en el horizonte, la del propio vudú, y de hecho, él, como funcionario de la UNESCO estaría colaborando a esa desaparición ya que el culto sobrevivía - en su opinión, que sesenta años después nos parecerá ingenua - por la miseria extrema que el programa internacional, finalmente abandonado, intentaba paliar. En palabras suyas:

El vudú $[. .$.$] está destinado a desaparecer, no bajo los ataques de la Iglesia, sino$ como consecuencia de los cambios que, tarde o temprano, la escuela y el hospital no dejarán de introducir. No olvidemos que, para millares de campesinos, el hougan (sacerdote) es el único médico y el santuario de los loa, el único dispensario. El vudú ejerce una función importante en la sociedad campesina y la seguirá ejerciendo mientras no sea reemplazado por instituciones que satisfagan las mismas necesidades. (Métraux 1953, p. 267)

Su posición es, pues, ambigua, paradójica. No puede evitar la enorme atracción que le produce ese culto mestizo y original, que remite tanto a África como a la Europa más auténtica, más arcaica; ese culto que moviliza las esperanzas de aquellos que, sin esa fuente de ilusión, serían presos de la desesperanza, del tedio, de la anomia; ese culto que lo conmueve por su belleza y su ingenua

1. La casualidad quiso que allí donde Métraux estuvo destinado por su trabajo en la UNESCO fuese también donde la campaña alcanzó su mayor éxito: «El valle de Marbial [...] sin duda es la única región de Haití donde el clero ha conseguido eliminar el vudú - al menos en la superficie » (Métraux 1953, p. 251-252). 
malicia. Pero, al mismo tiempo, no puede dejar de trabajar por un Haití que no necesite de tales ensueños. Es la paradoja que se explicitaba en que fuese, al mismo tiempo, un funcionario de un organismo internacional dirigiendo a un equipo, con un presupuesto en dólares, personal subordinado y una masa de campesinos expectantes de sus logros, y, por otro lado, un investigador sin más ${ }^{2}$. Dice Métraux (apud Laurière 2005, p. 198) en un artículo publicado en 1953 sobre la antropología aplicada:

La dirección del proyecto y la investigación etnográfica son absolutamente incompatibles. Una misma persona sola no puede a la vez encargarse de repartir las labores, contratar o despedir trabajadores [...] y, al mismo tiempo, ir de una choza a otra recogiendo informaciones sobre las creencias y las costumbres de las gentes. El etnógrafo está obligado a mostrar cierta humildad y una familiaridad en total contradicción con la actitud autoritaria que debe mostrar un administrador.

$$
* * *
$$

Christine Laurière (2005, p. 201) ya ha señalado que Le vaudou haïtien es una síntesis de observaciones y análisis tan condensada que no permite operar un nuevo resumen. Capítulo tras capítulo, sección tras sección, página tras página, el autor se desliza por todos los aspectos que conciernen a su objeto, enlazándolos para brindar al lector un enorme fresco que todo lo abarca. Una eficacia descriptiva tal sólo es posible por una acción artesanal de tanta destreza que se vuelve invisible ${ }^{3}$. Pienso que en un curso de metodología sería de mucho provecho destripar Le vaudou... para mostrar su making of; ése no es, sin embargo, el propósito de mi texto, aunque quiero al menos hacer una breve aproximación a las últimas páginas de la obra.

La dinámica entre el vudú y las denominaciones protestantes es una muestra de su prosa vívida y tan evocativa como reveladora. Con gran precisión, de manera en extremo concisa y con mucha perspicacia, Métraux muestra, sin expresarlo con todas las letras, que todo el campo religioso haitiano está habitado por las mismas entidades espirituales, ya las llamen loa, santos, ángeles caídos, demonios. Los curas católicos, muchos de ellos, creen en la realidad

2. Además de esta cuestión estructural insalvable, había otra, ya en relación con su puesto oficial en el valle de Marbial. Dice d'Ans (Métraux 1978, p. 222): «En Marbial, Métraux iba a encontrarse inevitablemente prisionero de su función de animador del proyecto. Aunque esta función no llegaba a hacerlo cómplice de los anti-supersticiosos, lo convertía de alguna manera en rehén. [...] su posición oficial hubiese impedido que Métraux se dejase ver allí como un observador benévolo, hasta simpatizante, del vudú ».

3. Destreza que parece mayor aún cuando se lee en una carta suya a Verger ( 7 décembre 1956): «Quiero quitarme de encima el vudú y me enmaraño en mis notas innumerables y difíciles de coordinar. Estoy sofocado por la exuberancia de mi materia » (Métraux y Verger 1994, p. 235). 
de estos espíritus, sólo que los interpretan de manera inversa a los vuduistas, como seres infernales, y, en vez de rendirles culto, quieren exorcizarlos. El mismo protestantismo, en sus diversas denominaciones, no es en verdad una religión tan ajena al vudú, como sus pastores querrían; por el contrario, el templo evangélico o baptista es el recurso último, la protección más radical contra el poder de los loa:

El protestantismo aparece, entonces, como un asilo o, más exactamente, como un círculo mágico en el que se está al abrigo de los loa. La conversión, lejos de ser el fruto de una crisis de conciencia es, demasiado a menudo, sólo la expresión de un miedo excesivo a los espíritus. (Métraux 1958, p. 312)

En siete páginas, Métraux aporta nueve casos conocidos por él de manera directa o indirecta de gentes que abandonaron el culto y se convirtieron a iglesias protestantes movidos por catástrofes vitales - enfermedad y muerte de hijos, pérdida de ganado, fracaso en los negocios, etc. - que los loa causaron o que no impidieron, a pesar de haber sido servidos por los sacrificios estipulados por los sacerdotes, y, también, de quienes hicieron el camino de vuelta y abrazaron de nuevo su relación con los loa. Lo que quiero destacar es cómo, con unos pocos relatos de escasas líneas, Métraux logra recrear la dinámica vivida del proceso, las ideas y sentimientos de las gentes, sus contradicciones y dilemas, las categorías ideales en juego tal como se hacen carne en ellas. Veamos un ejemplo:

Una tal Prudence, durante un servicio protestante en Marbial, sufrió una crisis nerviosa que apenas se distinguía de una crisis de posesión. La llevaron a toda prisa a su casa; su estado pareció tan alarmante que llamaron a su hijo, que aún practica el vudú. Se mandó a que un hougan organizase una ceremonia propiciatoria. Días más tarde, Prudence estaba totalmente curada. No le pareció necesario abjurar del protestantismo, pero cada año le da un dinero a su hijo que lo usa para hacer ofrendas a los loa. (Ibid., p. 314)

Esto es, en una palabra, lo concreto al que aspiraba su maestro Marcel Mauss. Es, en otra palabra, poesía, como apuntaría Michel Leiris (1992 [1963], p. 286), cuando, en un homenaje póstumo a Alfred Métraux, decía que éste estaba concernido por « una preocupación de orden propiamente poética: no contentarse con describir las cosas, sino, tras haberlas captado en toda su realidad singular, hacerlas vivir a los ojos de quien te lee $»^{4}$.

Como es evidente, lo puesto en obra aquí no se trata más que de una antropología posible, y para nada la más exitosa en el mundo académico, como decía con amargura, tras el suicidio de Métraux, Leiris en su prólogo a la segunda

4. Leiris ya había empleado una idea semejante, al hablar en L'Afrique fantôme (1996 [1934], 5.VIII.32) de su colaborador etíope Abba Jerôme: « [...] es un hombre que tiene instinto poético de la información, es decir, el sentido del detalle en apariencia insignificante pero que sitúa todo y da al documento su sello de verdad ». 
edición de Le vaudou... La hostilidad de la otra antropología, de la antropología sí exitosa, queda patente en la reprensión de Bourdieu (apud Debaene 2015, p. 265, n. 6) al esteticismo, al « culto artístico del exotismo » que une, en su parecer, a Métraux con Leiris y con Lévi-Strauss, correlativo al vínculo que en su juventud los tres tuvieron con el surrealismo. Una vez más Platón quiere expulsar a la poesía de la Ciudad. Y aunque no se pueda decir que Métraux haya sido expulsado, no escapa a nadie que la oscuridad que desde hace décadas rodea su figura no condice con la riqueza y amplitud de su obra.

\section{Eruditos, vuduistas, intermediarios}

Gran trabajo de síntesis, como dice Christine Laurière, Le vaudou... remite, además de a su propia observación y convivencia, a una serie de investigaciones anteriores o simultáneas ${ }^{5}$. Éstas no eran muchas, y, según Métraux (1958, p. 15) su calidad no llegaba a la de los estudios sobre los cultos afro-cubanos y afro-brasileños ${ }^{6}$. El paño de fondo de tales estudios era la profunda estigmatización que las elites de Haití imprimieron sobre todo lo que hiciese recordar el origen africano de la población del país y, fundamentalmente, de su aspecto místico. El vudú no podía considerarse como una religión, sino como un compuesto primitivo de supersticiones y hechicería ${ }^{7}$. Veamos, como ejemplo de esta actitud, lo dicho en una conferencia por el obispo de Cap Haïtien en agosto de 1896 (apud Hurbon 1998, p. 135): « La nación haitiana está enferma, profundamente enferma; sufre de paganismo. [...] Mientras el vudú exista entre nosotros, vano será cualquier esfuerzo de hacernos pasar por una nación verdaderamente civilizada ».

Jean Price-Mars, con quien Métraux estuvo en contacto durante su investigación, es la figura clave, el motor primero de la reacción contra el estigma anti-africano que tiene un contexto histórico muy claro. Los Estados Unidos habían ocupado Haití en 1915 y sólo se retiraron en 1934. Los motivos reales

5. Tras Le vaudou haïtien, al parecer, no se produjeron trabajos sobre la religiosidad haitiana. Según Nicolas Vornax (2005), las investigaciones etnográficas sobre el vudú, salvo estos últimos años, quedaron congeladas por medio siglo. Las razones, dice este autor, son múltiples; la represión del régimen de Duvalier hizo huir a quienes hubieran podido llevar a cabo esos estudios, la propia relación del dictador con el culto lo había desmerecido a ojos de los intelectuales; el nacionalismo de los años 1930-1940 había zozobrado o ya no podía tener en el vudú su piedra de toque.

6. No trataré en este artículo la compleja dinámica entre la investigación de Métraux y los estudios de la época sobre las religiones brasileñas y cubanas de raíz africana, cuestión sobre la que estoy trabajando en la actualidad.

7. Un eco de esta posición persiste en un investigador actual, cualquiera que sea su intención: «Hemos concluido [...] que había que definir al vudú como un sistema de cuidados con connotación mágico-religiosa en vez de definirlo de inicio como una religión » (Vornax 2005, p. 213). 
de la ocupación fueron, por un lado, una enorme deuda del país con empresas extranjeras, que los ocupantes saldaron con la confiscación del $25 \%$ de las rentas aduaneras, y, por el otro, la importancia creciente de la inmigración alemana en la sociedad haitiana. Los argumentos que justificaron la operación no eran tan crudos; además de grandes desórdenes y el consecuente aumento de la violencia política, la prensa americana echaba mano del salvajismo de esa república de negros, su idolatría, sus costumbres primitivas que tenían en el vudú su mayor exponente. Las tropas americanas actuaron en Haití con un grado de brutalidad extremo, provocando miles de muertos, quemando aldeas, haciendo que muchos campesinos abandonasen sus aldeas. Todo estaba permitido en nombre del primitivismo del otro.

Al mismo tiempo que una parte de la elite haitiana, fundamentalmente los mulatos, apoyaba la ocupación, surgía una nueva elite de intelectuales negros de la que Price-Mars es la personalidad más destacada. Precursor del movimiento de la negritud, en 1928 publicó su obra principal, Ainsi parla l'oncle, en la que reivindicaba la conciencia nacional haitiana, conciencia de los orígenes, conciencia negra. Los haitianos debían abandonar la sumisión tradicional a los valores franceses, renunciar al bovarysmo colectivo que les hacía querer ser algo que no eran.

Tres eran los elementos que debían ser rescatados del estigma en que las elites los habían confinado: las tradiciones orales, el vudú y el creole ${ }^{8}$, que abría el acceso a las dos primeras y, con ello, al pueblo haitiano, del que Price-Mars (2009 [1928], p. 26) sentía que él y la elite a la que pertenecía estaban separados por un abismo (« dos entidades aparentemente distintas y a menudo antagónicas »). Respecto del vudú, el golpe de timón frente a su estigmatización es la simple afirmación de que « el vudú es una religión » (ibid., p. 42), tras varias páginas en las que enumera las condiciones que una religión debe cumplir, y seguida de otras tantas que impugnan la negativa de los católicos a considerarlo tal por no compartir la misma visión moral.

Desmontar el estigma del vudú a ojos de la elite haitiana y de los extranjeros pasaba para Price-Mars por legitimarse a sí mismo como fuente erudita; al menos eso es lo que hace suponer el hecho de que su libro esté tan mechado de citas y más citas de Frazer a Durkheim, de Frobenius a Lévy-Bruhl, que sólo un letrado podría manejar. En uno de los trabajos que acompañan a la reciente reedición de Ainsi parla l'oncle, Laferrière (2009 [1928], p. 267) señala la paradoja de denunciar a Europa con argumentos europeos; completa su observación con

8. Métraux (1958, p. 18) comparte ese reconocimiento del creole: « No es una jerigonza grosera, como a menudo se ha dicho, sino una lengua de formación relativamente reciente que deriva del francés, como éste del latín ». 
un poema de Léon Laleau (Trahison) que termina así: " d'apprivoiser avec des mots de France/ ce cour qui m'est venu du Sénegal »".

Con igual propósito legitimador se propone quitar hierro a tres elementos del vudú que chocaban con las buenas maneras de la burguesía haitiana: danza, éxtasis y sacrificio (Price-Mars 2009 [1928], p. 136). Griegos, romanos y hebreos bíblicos - para mantenernos en nuestra tradición - tenían a la danza como medio de comunicación con las instancias sagradas; el sacrificio, cotidiano entre los dos primeros, no era ajeno a los últimos. El trance, la posesión, tampoco está tan lejos de lo aceptable, como lo revela una escena de « delirio místico » de la cual Price-Mars fue testigo en un templo baptista de Washington; algo más alejado, pero siempre dentro de la esfera de una religión de Libro, están los derviches y otros místicos islámicos ${ }^{10}$.

Ahora bien, junto a los amplios desarrollos teóricos y los ejemplos religiosos de otras latitudes, cuando Price-Mars habla directamente del vudú presenta descripciones tomadas, la mayor parte, de los pocos autores con los que podía contar en su momento. Material escaso, piensa Métraux (1958, p. 16), con un tratamiento que resulta 《demasiado tímido ${ }^{11}$. No por ello deja de reconocer el valor de Ainsi parla l'oncle, pero más que nada como desencadenante de una actitud diferente respecto de las manifestaciones de la vida cultural del pueblo haitiano.

Su continuador más brillante, que no podría haber sido acusado de tímido, fue Jacques Roumain, hombre de letras y fundador del Partido Comunista de Haití, que en 1941, durante la primera estancia de Métraux en la isla, lo introdujo en el ambiente vuduista. Roumain, con el apoyo de Price-Mars y la inspiración de Métraux, consiguió que el gobierno crease en 1941 el Bureau d'ethnologie de Haití, al mismo tiempo que, gran paradoja, éste desarrollaba la campaña contra el vudú (Charlier-Doucet 2005, p. 109). Roumain produjo un pequeño ensayo sobre la consagración de un tambor ritual - sintetizado por Métraux (1958, p. 164) -, que no era fruto de sus propias observaciones sino de conversaciones con un hougan renombrado, Abraham, con quien Métraux también trabajaría; su muerte tan prematura desbarató más aportes suyos sobre el vudú.

9. No es la única crítica, ni la más suave, contra Price-Mars, a quien se le recrimina con mayor o menor fuerza una cierta complicidad con Duvalier: el haber consentido en silencio que la dictadura utilizase sus trabajos como sustento ideológico. Así, René Depestres (apud Dash 2009 [1928], p. 338) le reprochaba no haber desautorizado « a quienes se habían servido de su autoridad intelectual para emplear el concepto de negritud con fines escandalosamente oscurantistas ».

10. Una curiosidad. Para hablar de los derviches, Price-Mars (2009 [1928], p. 152) echa mano, entre otros, de un artículo de Seabrook, quien años más tarde escribiría sobre el vudú.

11. No obstante, Métraux (1958, p. 272) toma de Price-Mars la rara descripción de una acción de anti-hechicería, el encadenamiento de loa, « rito generalmente realizado en el mayor misterio ». 
Métraux también hace unas pocas referencias puntuales, circunstanciales, a lo que denomina « autores nacionalistas contemporáneos » como Lorimer Denis $^{12}$ y François Duvalier, así como a personajes muy curiosos: el militar Luis Maximilien y Milo Rigaud, « dominado por preocupaciones ocultistas y (que) escapa por tanto a la etnografía ». Eso en lo relativo a los estudios nativos.

Aunque hay además dos textos «nativos » muy peculiares, uno de Odette Mennesson-Rigaud (1946), el otro de Émile Marcelin (1947), ambos prologados por Métraux, ambos redactados a su pedido y con su intervención, ambos casi con la misma fecha. Los dos artículos son producto de notas previas de los firmantes, seleccionados por Métraux, que tiene un papel decisivo en la revisión y confirmación de los datos mediante entrevistas con agentes y clientes del culto.

Odette Mennesson-Rigaud era una francesa casada con Milo Rigaud, que aparecía en la primera línea de la primera anotación de 1944 del diario de Métraux. Fue figura clave de su investigación, como él mismo reconocería en la dedicatoria de su libro ${ }^{13}$, a quien desde un comienzo había pretendido hacer escribir sobre el vudú ${ }^{14}$. Su trabajo, de unas cincuenta páginas, es la descripción de una ceremonia, mangé loa, en la que se realizan una serie de sacrificios animales y otras ofrendas, con el propósito de restaurar la energía que las divinidades gastan en acudir en beneficio de sus fieles. El de Marcelin, de una dimensión semejante, es una enumeración de algunas de estas divinidades con breves datos mitológicos, su correspondencia con figuras del panteón católico, descripciones de sus desempeños corporales cuando « cabalgan » a sus fieles, cantigas que les son dedicadas, etc ${ }^{15}$.

12. Pomposo y estúpido, lo llama en sus notas Métraux (1978, p. 235), pero más que eso fue el inseparable colaborador de Duvalier, uno de los gestores del particular fascismo racista en que basaría ideológicamente su dictadura.

13. «A madame Odette Mennesson-Rigaud, mambo (sacerdotisa) Assurée, sin cuya ayuda este libro no hubiera podido escribirse ». Esta dedicatoria estaba precedida por otra, a la entonces ya fallecida mambo Lorgina Delorge, que Métraux había conocido gracias a Odette. Ésta no desaparecería de la vida del etnólogo tras su experiencia haitiana, sino que seguiría en contacto con él, como se evidencia en diversos trechos de su correspondencia con Verger (Métraux y Verger 1994, p. 144, 209, 222, 225), en alusiones a veces irónicas, y en diversas anotaciones recogidas en Itinéraires (Métraux 1978, p. 359, 374, 377, 379, 385).

14. El día que la conoció, Métraux escribe: « Milo Rigaud, el marido de Odette, está en prisión a consecuencias de un juicio que intentó contra el presidente Vincent. Es un artista pintor, escritor que dicen con talento; se entrega al ocultismo. Ella es una parisina de tipo argelino, que ha frecuentado la bohemia de Montparnasse. Vive en un mundo extraño, en el límite entre el vudú y el ocultismo. Sabe muchas cosas y acumula conocimientos varios con fines oscuros. Hay que animarla a que escriba. »

15. El original redactado en francés fue vertido al inglés por Métraux y su esposa Rhoda. 
Los prólogos de ambos artículos podrían considerarse un texto único ${ }^{16}$, inicio de dos secciones articuladas, una descripción etnológica global a cargo del prologuista, una etnografía (dos etnografías) que enfatizaba quizá de manera algo forzada, quizás algo engañosa, que eran la voz directa de los nativos: una suerte de auto-etnografía. La etnología era una sinopsis de lo que doce años más tarde aparecería en Le vaudou haïtien, desde la multiplicidad de estilos devocionales vuduistas hasta la teatralidad de la posesión y la amnesia (fingida o real, " personne ne le sait ») posterior al trance, desde la propuesta de descomponer las ceremonias en unidades rituales, especies de ritemas que se articulan de una u otra manera, a la similitud de estos rituales con los del cristianismo arcaico europeo o los misterios griegos, etc.

En fin, el punto es que ya Métraux tenía en mente un mapa de la realidad del vudú y sabía cómo debía encarar su investigación. La forma de trabajo establecida era la de una primera aproximación mediante « informantes cualificados », a la que seguían entrevistas a múltiples agentes y clientes, con ayuda a veces de los primeros informantes, todo esto articulado sobre la presencia continua del investigador en los centros de culto, tanto durante la realización de ceremonias cuanto fuera de ellas, lo que le permitía tomar el pulso del cotidiano de las agencias.

Están también los trabajos americanos, entre los cuales un par de autores resultaban tan excéntricos como excéntrico - o más que excéntrico, maligno, tenebroso, abominable - era el vudú para la opinión estadounidense de los años 1930. Una es Zora Neale Hurston, una afroamericana dedicada a todo tipo de actividad cultural (ensayo, novela, folklore) con la cuestión negra como centro, mucho más apreciada en la actualidad que en su tiempo. De todas maneras, Franz Boas la tenía en alta estima - prologó un libro suyo - y para él llevó a cabo investigaciones en Harlem y en el sur de los EEUU. Realizó varias estancias en Jamaica y Haití en 1937 con becas Guggenheim, producto de las cuales es Tell my horse. Voodoo and life in Haiti and Jamaica de 1938. Métraux (1958, p. 249) no la veía con mucha simpatía - la considera « muy supersticiosa $»-$ y se enfrenta a ella por dar por cierta la existencia de los famosos « zombis » (Hurston 1990 [1938], p. 184-185); así, ignora su vigorosa etnografía, salvaje si se quiere, pero cargada de información.

Hay de hecho hallazgos suyos a los que Métraux hubiese debido prestar más atención, como el juego de representaciones entre las litografías católicas, sobre las que escribiría Leiris (1953) quince años más tarde, y las otras imágenes

16. Hay un tercer texto de la misma época, un breve artículo sobre el alma vudú, basado en entrevistas a informantes del Bureau d'ethnologie, con la colaboración de Denis y de la infatigable Odette. El elemento ritual más significativo, que Métraux (1946, p. 88 y s.) no ha aún presenciado y que registra por el relato de informantes, sigue la dirección inversa del mangé loa de artículo de Mme Mennesson: alimentar a la cabeza del fiel, no ya a los dioses. 
dibujadas en los templos vuduistas por los sacerdotes, más fieles a la idea que tienen de los loa. La razón por la que los vuduistas compran y emplean las primeras, dice Hurston, es que « quieren alguna representación visual de los invisibles y hasta ahora ningún artista haitiano les ha dado una interpretación del concepto de los loa. Pero hasta el campesino más iletrado sabe que la imagen del santo es sólo una aproximación del loa » (1990 [1938], p. 114) ${ }^{17}$. Según Métraux (1947, p. 56), el mecanismo por el cual las divinidades del vudú se han identificado con personajes del panteón católico parte de estas

groseras cromolitografías. [...] La fisonomía y los atributos de cada santo han sido interpretados según la mitología vudú y ha bastado a menudo un detalle insignificante para establecer una equivalencia. San Patricio es el dios serpiente Damballah porque ha expulsado las serpientes de Irlanda y éstas están a sus pies.

El otro escritor es William Seabrook, un personaje muy atípico (bastante mitómano, anota Métraux [1958, p. 11]), con una vida demasiado agitada como para poder sintetizarla aquí, que publicó en 1929 un libro sobre el vudú, comentado por Leiris elogiosamente en Documents. Muestra sobre el vudú una visión que al menos en un aspecto no es tan lejana a la de Métraux: « [...] el vudú, en Haití, es una religión viva, por no decir vital. Una religión tan viva y vital como lo fue el cristianismo en sus comienzos y en la primera Edad Media, cuando los milagros se daban cada día, como la cosa más natural del mundo » (Seabrook 2005 [1929], p. 42). Pero hay más que una coincidencia de visiones. El viajero americano había descrito un sacrificio que condecía con sus tendencias ocultistas y su exhibicionismo: sexo y sangre se unían en un vértigo que casaba con la visión tremendista que en los Estados Unidos se habían forjado del vudú (ibid., p. 237). Métraux (1958, p. 152) pone las cosas en su lugar, quita el color fantástico y novelero del registro para dar una versión que tampoco resulta muy tranquilizadora: una cabra que ocupaba, a último minuto, el lugar de una mujer bajo el cuchillo del sacerdote.

Hubo otros investigadores americanos, y Métraux los cita y utiliza sus datos (Simpson, Parsons, Courlander). Sin embargo, le queda claro que su perspectiva folklorística, el afán coleccionista de cantos, danzas o registros rituales, por más que brinde una información valiosa, no conduce a donde él quería llegar.

17. Hurston fue objeto de la crítica de los militantes negros vinculados al Partido Comunista, como Richard Wright: « Al celebrar el folklore de los negros, Hurston despertaba la sospecha de querer negarles el derecho a la modernidad y a la igualdad de trato, y confinarlos en un pasado exótico y encantador, una imagen que convenía a los clichés racistas sobre un pueblo de niños con pensamiento mágico, perdidos en una nación civilizada de la que no comprendían nada » (Parent 2014, p. 61). Pero en verdad, la escritora « definía la cultura negra americana por la creatividad sin límites a partir de material ajeno » (ibid.), lo que a mi entender es la característica misma de la subalternidad en un sentido muy cercano al dado por Gramsci, que para nada es una condición racial, sino social, política y cultural. 
Sin dudas Herskovits (2012 [1937]), que contó con la ayuda de Price-Mars para llevar a cabo su trabajo de campo, significó un cambio de registro. En Le vaudou..., es el investigador a quien Métraux más cita, en algunos casos como referencia general, mientras que en otros toma descripciones suyas de acciones rituales como el lavado de cabeza, o el registro en Benin (Dahomey) de cantos ceremoniales en los que se invocaba a los dioses para que impidiesen nuevas capturas de esclavos, que se castigase a los compradores de los que ya habían sido vendidos y que recompensasen a los supervivientes con tejidos, ron, pólvora o armas de fuego. Cualquiera que fuere el valor de la investigación de Herskovits, sin embargo, su perspectiva había sido la opuesta a la de Métraux, la búsqueda de los vestigios de distintas culturas africanas en Haití.

$$
* * *
$$

El primer contacto de Métraux con Haití y, de mano de Roumain, con el vudú, se dio durante un breve viaje turístico suyo en el verano de 1941; cuando regresó en 1944, su conocimiento del culto debía ser tan extenso como para que las anotaciones en su diario estuviesen redactadas con una terminología muy técnica; de hecho, d'Ans, el editor de Itinéraires ..., se queja de que « en ciertos momentos [...] las descripciones de ceremonias, danzas y posesiones, en estilo telegráfico, mitad en francés, mitad en creole [...] son difíciles de descifrar ».

¿Acaso esos conocimientos provenían todos de las lecturas que Métraux pudo haber hecho en esos tres años de ausencia? Supongo que quien susurraba en sus oídos buena parte de los términos que desconciertan a d'Ans era Odette Mennesson-Rigaud, pero no es ella la única intermediaria con los practicantes del vudú. Roumain, con quien tan bien se había llevado en su primera estancia en Haití, había muerto, pero en las notas recogidas en Itinéraires no paran de aparecer los estudiosos del culto que antes he nombrado y otros más (los hermanos de Émile Marcelin, Louis Mars), así como también vuduistas de a pie o agentes del culto. Con algunos Métraux llega a salir de caza de mujeres livianas (1978, p. 248), no sabemos con qué éxito. Otras veces la presa es una vuduista, que - dice Métraux (ibid., p. 266) - parece fingir la posesión para rehuir sus avances.

También realiza continuas visitas a casa de Lorgina, muchas veces solo, otras con Odette Mennesson-Rigaud, contra quien la mambo advierte a Métraux (ibid., p. 238): no tiene que confiar en ella. Es el tipo de desavenencia que con tanta facilidad nace y muere en una agencia religiosa de este tipo. Asiste a ceremonias en muchos templos. El de Lorgina es una choza miserable, algunos son todavía más pobres, pero otras veces es invitado a templos frecuentados por la burguesía, ricos y lujosos, a los que acuden todos aquellos que son alguien en el mundo del vudú, y en cuyas ceremonias el champán se derrocha; en algunos casos es un simple espectador, en otros tiene un papel visible (padrino en una 
boda mística); se sumerge así en un arco muy amplio del universo vuduista. En fin, nada más alejado de un frío observador: Métraux observa y participa, participa y observa, y es este continuo estar en campo lo que se refleja en su obra y le proporciona tanta riqueza.

\section{Las dimensiones de Le vaudou haïtien}

Cualquiera que sea el grado de utilidad que Métraux haya encontrado en sus antecesores en el estudio del vudú, haitianos o americanos, pretendía en su libro hacer una especie de giro copernicano: abandonar las largas descripciones ceremoniales que tanto abundaban para, a partir de ellas, abordar una vía nueva. En una reseña de un libro sobre músicas y danzas vudú de Harold Courlander, al mismo tiempo que elogiaba la riqueza de los materiales allí aportados, Métraux (1962, p. 122) reconocía que era una «presentación muy poco sistemática del vudú » y continuaba:

[...] uno puede preguntarse si es útil continuar acumulando descripciones de las fiestas vudú o si no ha llegado el momento de dedicarse al análisis de los elementos rituales de los que están compuesta su estructura y que, poco modificados, se repiten en un orden variable.

Ésa fue su tentativa en Le vaudou... (Métraux 1958, p. 141): « Empezaré por despejar de la masa de mis observaciones los elementos fundamentales que se combinan para constituir lo que los haitianos llaman un "servicio" ". La descripción y el análisis de esos segmentos ceremoniales ocupan casi un tercio del libro, pero por más que la información allí vertida es preciosa, no termina de definirse con claridad el criterio de determinación de esas unidades elementales del ritual, de esa suerte de « ritemas »: Métraux presenta esas acciones rituales - los complejísimos saludos entre los oficiantes, las invocaciones o las libaciones, etc. - junto a ceremonias - la fiesta de los ñames, los ritos de iniciación, etc. - que ya representan la fusión de unidades menores, o a elementos materiales e inmateriales (instrumentos musicales, canciones, danzas) empleados en las ceremonias. Quizá la propuesta de Métraux, más que una suerte de cuerpo constituido y cerrado, nos brinde un principio regulador, bajo la idea de que lo que importa en los rituales no es tanto la serie de acciones que puedan describirse, sino su sentido, y que la labor del etnólogo es lograr despejarlo ${ }^{18}$.

Otra diferencia con la mayoría de los estudios anteriores sobre el vudú es el no embrollarse en la enumeración y clasificación de los loa, preocupación

18. Métraux (citado por Poitry 1999, p. 7) escribe en 1937 una carta a Leiris, con quien ya veremos hasta dónde más tarde estuvo unido: «He hojeado su artículo sobre la circuncisión entre los dogon. Temo que tenga usted una concepción triste y mecánica de la etnografía; la descripción por la descripción no tiene ningún sentido ». 
de quienes Métraux llama, con cierto retintín, « los teólogos del vudú ». Milo Rigaud (1953, p. 141 y s.), el marido de Odette, sin duda uno de estos pretendientes a teólogos, computaba varios centenares, sólo para reconocer que se trataba de una lista incompleta que ni con cien páginas podría darse por cerrada. Ese, tal vez, era un punto de concordancia entre Rigaud y Métraux: todos los días en las agencias vuduistas surgían nuevos loa.

El principio operativo en la opción de Métraux era la perspectiva etnológica con la que introducía el libro, el no dejarse encandilar por quienes, dentro del culto, pudiesen pretender, por formación, o por pertenencia social, cierta complicidad con el observador. No son las capas más letradas las que mejor pueden dar cuenta de la realidad del culto ${ }^{19}$. La realidad del culto, o en verdad, sus realidades, hay que rastrearla en el funcionamiento cotidiano de las agencias, cuanto más alejadas de los centros de poder político o académico, mejor.

La camisa de fuerza que los sectores eruditos del vudú han querido imponer a la dinámica del culto es - no lo dice Métraux, lo pienso yo desde la experiencia afro-brasileña - un instrumento de poder, la conformación de una elite que operase a nivel nacional y que pusiese el vudú en el mismo plano que las religiones eruditas ${ }^{20}$; a tal fin, nada mejor que grandes organigramas de entidades místicas meticulosamente estructurados. Por su parte, Métraux (1958, p. 75 y s.) opta por registrar el tipo de clasificación significativa para el pueblo vuduista, la base de la inmensa masa de adeptos, a la que poco le interesan las prolijas disquisiciones de letrados y semi-letrados: una dualidad entre loa petro y loa rada, así como una clasificación transversal a ésta entre diversas « naciones » (« numerosos sub-grupos de genios que llevan el nombre de tribus africanas $[\ldots]$ o de regiones de África $[\ldots] »)$.

Como estudio de un culto afro-americano, el libro de Métraux inauguraba una tradición que sólo décadas más tarde, y de manera minoritaria, sería continuada. En efecto, subrayaba la génesis nacional y la radical originalidad del vudú al tiempo que exhibía su escaso interés por su africanidad, el polo opuesto a la idea de « religiones africanas en Brasil » de su amigo Roger Bastide. Dice Métraux (1958, p. 52):

19. Un punto más en que sintoniza Métraux con Leiris (1996 [1934], p. 579), quien en Etiopía prefiere una « informante » que reconoce su ignorancia sobre las interioridades del culto de los espíritus zar, ya que así se vuelve « su testimonio más puro y más vivo ».

20. En noviembre de 2015 ha muerto Max Beauvoir, el caso más extremo de los miembros de esta elite, considerado « jefe supremo de la religión vudú en Haití ». Estudiante de química en Estados Unidos y Francia, en 1974 volvió a su tierra y comenzó a montar ceremonias vudú para los turistas. Su gran ingenio y su audacia le permitieron vincularse a autoridades políticas pos-Duvalier al mismo tiempo que organizaba federaciones vuduistas que lo eligieron jefe supremo en 2008. 
[...] la pureza de la herencia africana nos interesa poco ${ }^{21}$. El vudú merece ser estudiado no sólo en función de la supervivencia de creencias y prácticas dahomeyanas o congoleñas, sino también como un sistema religioso nacido en época reciente de la fusión de elementos diversos. Su aspecto dinámico que continúa evolucionando ante nuestros ojos, es lo que centrará nuestro interés, más que la rica materia que ofrece a los eruditos apasionados por la búsqueda de las fuentes.

África está sin duda presente en el sistema de creencias y prácticas del vudú, pero también lo está, de una manera que los estudiosos de las religiones afro-americanas en la época no quisieron ni sospechar, una profunda tradición mediterránea, europea ${ }^{22}$. Los orígenes helénicos de nuestra civilización están presentes en los cultos haitianos:

Entre un houmfô (templo) haitiano y un santuario rural de la antigua Grecia la diferencia no es muy grande. [...] A pesar del color de sus adherentes, lo que descubrimos con alegría o con horror según nuestro temperamento o nuestra formación es un paganismo de Occidente. No es África lo que debemos ir a buscar en Haití, sino nuestra vieja herencia clásica. (Métraux 1957, p. 83)

Una y otra vez Métraux remite a la tradición mediterránea. La propia hacha con hoja doble de Xangô, que vemos en Haití como en Brasil y en Cuba, tendría, según Métraux (1958, p. 23), su raíz en Cnossos. Seguramente sin saberlo, apuntaba al complejo extático mediterráneo que Ernesto Di Martino ${ }^{23}$ esbozaba más o menos en las mismas fechas en su estudio sobre los atarantados de Lucania, complejo al que Leiris (1996 [1958], p. 923 y s.) apuntaría en su escrito sobre los espíritus zar en Etiopía. Su intuición, a la que, que yo sepa, nadie ha prestado atención, daba lugar a una nueva interpretación del llamado « sincretismo »:

21. Métraux (1958, p. 82) tampoco creía pertinente establecer jerarquías entre agencias vuduistas o entre formas de llevar a cabo el culto: « La noción de tradición pura o impura es ajena al vudú; más bien es cuestión de intelectuales haitianos que trazan una línea de demarcación algo arbitraria entre prácticas que les parecen auténticas y otras que consideran adulteradas. He escuchado gritar a un escritor indignado, en medio de una ceremonia: “¡Pero estos ritos contradicen la filosofía vudú!" "

22. Para René Depestre (1968, p. 173), fue porque Price-Mars no había reparado en esto que su pensamiento pudo ser capitalizado por el régimen duvalierista: « Por no haber podido dilucidar con claridad el fenómeno del mestizaje cultural (entre los aportes africanos y los franceses), que se manifiestan también en el vudú, Price-Mars hizo posibles las extrapolaciones extravagantes, las contorsiones ideológicas que cultivaron posteriormente en Haití los malos lectores de Ainsi parla l'oncle, como Duvalier y otros paladines defensores de la negritud totalitaria. »

23. «[...] existió un complejo arcaico proto-mediterráneo, cuyas estructuras se mantienen no sólo en el coribantismo, el tarantismo apuliano y las formas afines sardas e ibéricas, sino también en los cultos africanos tipo zar y bori, y en sus prolongaciones y evoluciones afroamericanas » (Martino 1999 [1962], p. 239). 
[...] existe entre las civilizaciones mediterráneas y las que han florecido a lo largo del golfo de Guinea un fondo común de tradiciones religiosas, sociales, morales y estéticas [...]. Cuando negros y blancos se encontraron sobre tierra americana fue cuando estos parentescos espirituales intervinieron para, por una parte, facilitar la asimilación de los primeros a la civilización occidental y, por la otra, para enriquecer a ésta de elementos africanos. (Métraux 1951, p. 13)

Para Bastide, Herskovits o Verger, África es África, y Europa es Europa, casi como hipóstasis antagónicas; además, lo que más importa es que estos autores pierden de vista por completo las enormes diferencias entre las tradiciones religiosas africanas y el candomblé, la santería y el vudú. Métraux, por el contrario, muestra el carácter original de este último, la manera en que ha canibalizado ${ }^{24}$ diversas fuentes, sin menospreciar hasta la insospechable masonería, pero teniendo como referente primero al catolicismo. Este es otro punto de divergencia con la línea mayoritaria en los estudios afro-americanos, para la que el llamado sincretismo, la fusión de figuras del panteón católico con figuras africanas, es una astucia de la resistencia esclava. Lo leemos en las palabras de un sociólogo y teólogo haitiano, uno de los estudiosos actuales más visibles del vudú, Laënnec Hurbon (1998 [1994]):

La prohibición que atañe a las tradiciones religiosas africanas se ve burlada por la práctica - obligatoria - del cristianismo. El esclavo se apropia del culto de los santos, los sacramentos, las procesiones y todas las grandes fiestas litúrgicas; y crea con todo esto un dispositivo protector de las creencias africanas.

Para Métraux (1958, p. 291) lo que está en juego no es un fraude, sino, por el contrario, la sincera aceptación del valor y el poder de las creencias de los amos, y, por lo tanto, su apropiación, su canibalización: « Al imprimir un sello católico a ceremonias que poco tienen de tal, los vuduistas de ninguna manera buscan dar el cambiazo a las autoridades o a la Iglesia; convencidos de la eficacia de la liturgia católica, quieren que de ella se beneficie su religión particular ».

No se trata, pues, de una simple astucia infantil, del disfraz de las entidades místicas propias en el ropaje de entidades dominantes. Se trata de una astucia, si ése es el término, mucho más compleja, en la que la resistencia se conjuga con el sometimiento; el dominado, el subalterno, se apropia de los instrumentos religiosos que habían favorecido su derrota. Un obispo citado por Métraux (ibid.) lo decía con toda claridad: « Nosotros no hemos logrado cristianizar a esta gente; son ellos quienes se servían de nosotros para hacer la superstición ». Aunque el provecho puede ser considerado mutuo: « Casi se podría decir [...] que el

24. Métraux (1953, p. 14) formula así esta apropiación según la lógica propia: « [...] se manifiestan sorprendentes esfuerzos de reinterpretación. Éstos apuntan a aspectos importantes de la civilización europea que no son adoptados sin más, sino modelados en conformidad a un modelo cultural africano ». 
vudú, al absorber numerosas prácticas católicas, ha contribuido a mantener en el pueblo la tradición católica » (Métraux 1957, p. 23).

En su reseña de Le vaudou..., Roger Bastide (1960, p. 119) subrayaba que el vudú, como dice Métraux, representa un empobrecimiento del patrimonio africano. Pero para éste, y a Bastide no se le escapaba, esa decadencia representa vitalidad para el culto haitiano. Mientras que para Métraux lo que contaba era la rica originalidad creada por ese pueblo descendiente de esclavos, Bastide rescata de la obra aquello que podía orientar futuros estudios en África, a partir de elementos que allí perdidos pero que en Haití habían sobrevivido.

Lo del empobrecimiento, pienso yo, es más que discutible. Para Bastide tal decadencia se mostraba en el hecho de que en el vudú sólo había fragmentos inconexos de mitos de las divinidades africanas, a diferencia de lo que supuestamente ocurría en Benin o Nigeria. Pero su prejuicio logocéntrico, si se admite el término, le ocultaba lo cuestionable de ese supuesto « corpus mítico » y su imprecisa relación con alguna práctica religiosa concreta.

Por otra parte, la falta de esa mitología era compensada, y más que compensada, por una serie interminable de relatos sobre los peligros acarreados por los loa, por desatenderlos, por desobedecerles, o, al margen de cualquier actitud del sujeto, por convertirse en blanco de la manipulación mística del hechicero. Leamos las palabras de Métraux (1958, p. 81):

Ya no subsiste casi nada de los mitos africanos que relatan el origen de los dioses, sus aventuras y su papel cósmico. Con mucho trabajo se puede obtener de los sacerdotes informaciones confusas y a veces contradictorias sobre las relaciones de parentesco entre las divinidades y cosechar algunas anécdotas escandalosas sobre sus amores. La mitología [...] se ve rebajada a meros trapicheos, a cotilleos de aldea; se interesa menos por la vida personal de los espíritus que por su relación con los fieles. [...] La mayoría (de los relatos) tienen como tema ya las intervenciones de los loa a favor de sus servidores, ya los castigos a quienes los desatienden ${ }^{25}$.

Este corpus gigantesco e inagotable encierra una estructura narrativa productora de sentido, como he mostrado en otro lado $^{26}$, y en él yace la clave del

25. Un ejemplo sobre las desgracias de gentes que habían abandonado el vudú por el protestantismo (Métraux 1953, p. 265): « Una familia [...] había heredado dos houmfó (templos), pero había "renunciado" sinceramente. Una de las hijas de la casa que pasaba un día junto a una palmera consagrada a los loa sintió que algo pesado caía en su canasta. Cuando volvió a su casa vio que se trataba de una piedra pulida que tuvo la imprudencia de tirar a la ruta. Murió poco después. El pastor protestante hizo cortar la palmera, pero no la pudo partir para hacer leña. Los loa, irritados por este nuevo sacrilegio, mataron también a una de las hijas de su antiguo servidor y a uno de sus primos. »

26. Es lo que llamo « esquema etiológico » (Giobellina Brumana 2003 [1999], p. 120 y s.), un sistema que gráficamente está representado por un plano cartesiano en el que abscisa y ordenada son las vías de amenaza y de defensa místicas que permiten interpretar y resolver el daño sufrido por un sujeto. 
funcionamiento de religiones como el vudú, o de las religiones subalternas en general. Estamos, creo, ante otro tipo de mitología que provee a los vuduistas de un continente simbólico que todo lo abarca, de un código místico que todo lo interpreta, de un instrumento de intervención que a todo se enfrenta ${ }^{27}$.

En fin, el libro de Métraux nos brinda varias innovaciones teóricas y metodológicas claves: 1. la búsqueda de una suerte de sintaxis ritual, 2. el ir por detrás de las formulaciones letradas del culto para centrarse en las prácticas reales, 3. el reconocimiento de la originalidad del vudú y de que sus raíces son tan europeas como africanas, 4. el rechazo a que el catolicismo de los vuduistas fuese una mera artimaña, y 5. la revelación y registro de un plano narrativo que sustituye el relato de los avatares de los dioses por el de su influencia en la vida de los humanos, en fin, una nueva mitología.

\section{Métraux y Leiris, una convergencia con efectos colaterales}

A pesar de haberlos detectado, y de que registrase muchos de ellos, Métraux no se interesó lo suficiente por esos cotilleos aldeanos y no dio el salto que hubiese puesto a estas estructuras narrativas en el centro de atención; en cambio fue muy sensible al enorme logro estético del aparato ritual del culto, que se contraponía a la supuesta pobreza mitológica y abría una dimensión nueva - que no iría a recorrer - al pensar en el vudú como una « religión danzada » (1958, p. 23 y 168). Aquí el camino de Alfred Métraux confluye con el de Michel Leiris, tanto en su concepción novedosa de la posesión, como en la relación apasionada con campo y la fascinación por el universo negro. « Como usted » - escribe Métraux a Verger (28/05/1954) - « es hacia el mundo negro y el lirismo de sus culturas hacia donde me lleva mi ser » (Métraux y Verger 1994, p. 196). Leiris, que tan intensamente había vivido su experiencia africana en la Misión Dakar-Yibutí, podría haber dicho lo mismo.

Métraux y Verger habían trabajado juntos en Haití; uno aportó textos, el otro, fotografías: es el bello álbum Haïti. La terre, les hommes et les dieux y el número sobre poetas haitianos de Présence africaine. Y en esta última publicación aparecía un trabajo de Leiris, "Sacrifice d'un taureau chez le Hougan Jo Pierre-Gilles »; la colaboración ahora era entre textos, o, mejor, entre pre-textos, entre etnografías, en lo que D’Ans llama « jam-session etnográfica » (Métraux 1978, p. 233).

Con Leiris, Métraux converge en la resolución estrictamente antropológica de la cuestión central de la posesión, la de cómo interpretar la supuesta amnesia

27. Habría otro plano discursivo que también podría considerar parte de este nuevo corpus mitológico, al menos como complemento de los « cotilleos de aldea »: los diálogos entre loa, sacerdote y público, de los que Métraux (1958, p. 195-199) registra una sesión dirigida por Lorgina llena de amenazas místicas. 
que los sujetos del trance afirman experimentar en su transcurso: según el código del culto, tras el fin del trance, quien ha cedido su cuerpo para que una entidad mística, divinidad o espíritu de muerto actuase ceremonialmente, danzase, hablase, consumiese bebidas o tabacos emblemáticos, etc., dice que nada recuerda de lo ocurrido. Ni mistificación ni psicopatología, respuestas hasta entonces propuestas por los estudiosos, Leiris y Métraux, ambos por separado, y más o menos en la misma fecha, abordan el fenómeno con la propuesta de lo que el segundo llama « comedia ritual» y el primero « teatro vivido ». El sistema del culto proporciona a sus fieles los perfiles y pautas de desempeño de las entidades que deben ser encarnadas; desencadenada la acción ritual, en la que cada cual debe ajustarse a lo que se espera de sí:

En las capas populares (haitianas) la existencia de los loa y sus encarnaciones son artículos de fe. El poseído comparte esa convicción. En el estado de tensión en que se encuentra tras haber sufrido o simulado una crisis nerviosa, apenas distingue su « yo » del personaje que representa. Se improvisa actor. [...] Asume su papel de buena fe, atribuyéndolo a la voluntad de un espíritu que, de manera misteriosa, se ha insinuado en él. (Métraux 1958, p. 124)

Sale a luz así una perspectiva estrictamente maussiana, semejante a la que el Maestro abría al tratar las lágrimas: de nada sirve conjeturar lo que ocurre en la caja negra de la subjetividad de los sujetos (de quienes lloran, de quienes entran en trance). La respuesta que nos orienta es la que apunta a las categorías sociales que operan en un caso y en otro, en la constricción que estos sujetos tienen para adaptarse a ellas.

La teatralidad del vudú, de los cultos de posesión, no es una intervención teórica del observador, sino tal vez el aspecto más inmediato, más visible del fenómeno. El vudú proporciona a los campesinos, dice Métraux (1951, p. 17),

la mayor parte de las recreaciones estéticas que rompen la monotonía de su dura existencia. El papel del vudú en la sociedad haitiana es, pues, idéntico al de los cultos rurales de la antigüedad o de la edad media. Los santuarios vudús son a la vez iglesias, clubs, discotecas y teatros ${ }^{28}$.

Esta coincidencia conceptual entre Métraux y Leiris se producía desde vivencias propias, alejadas en el tiempo y en el espacio: la de éste en la Etiopía de comienzos de los años 1930, la de aquél en el Haití de una década posterior. Esas

28. «En sus comienzos, por cierto, la tragedia griega se parecía a lo que todavía se ve [...] en los ritos vuduistas: posesión del actor que en verdad está inspirado por el dios e interpreta menos de lo que encarna; indistinción completa entre actores y público, ya que el coro, en su origen, no era otra cosa que la multitud en asamblea para asistir al drama sagrado que se consumaba. Música, además, y danza, que se combinan con la acción del principio al fin; el ritual se desarrolla según un ritmo y todas las partes de que se compone se ajustan como figuras de ballet » (Leiris 1992 [1949], p. 84). 
semanas de 1948, sin embargo, envuelven a ambos en una experiencia común, en esa cápsula, esa encrucijada mágica (Leiris 1992 [1949]), esa aislada isla paradisíaca que Haití es para uno y otro ${ }^{29}$. Ese paraíso también tiene su árbol del bien y del mal; ese paraíso tiene también un fruto arrancado y consumido indebidamente. Leiris, de mano de Odette Mennesson-Rigaud ${ }^{30}$, presencia el sacrificio de un toro en un templo, registra en su diario la experiencia y, tiempo más tarde, publica esas páginas como el artículo ya mencionado en el número especial de Presence africaine.

De la misma manera que en L'Afrique fantôme, lo hace sin modificar nada, permitiendo la identificación de su guía y del sacerdote. Pero, como dice Jamin (2005, p. 228), mientras que los habitantes de Gondar o de Sanga nunca hubieran podido acceder a su libro, en Haití sí hubo quien leyó el texto de Leiris y se creó así una situación de mucho malestar para Odette Mennesson-Rigaud. No era para menos. Leiris (1951, p. 23 notas 2 y 3), además de otras indiscreciones, vierte comentarios de ésta, que poca gracia le haría que fuesen más allá del oído del etnólogo, desde el menos importante de que el templo visitado había tenido tiempos mejores hasta el dato grave de que el sacerdote actuaba en forma encubierta también como hechicero y que algo tenía de « hombre-lobo ».

Jamin vierte el contenido de una carta que la guía de Leiris le envía a éste: pena e indignación se conjugan en el reproche a quien no tuvo la prudencia de ocultar, además de sus confidencias, nombres y lugares de agentes y practicantes de un culto prohibido, que podía sobrevivir sólo por la benevolencia de algunas autoridades, las que, ante una publicación europea, ante un documento producido por un blanco, quedaban en una posición falsa. En fin, cargadas de razón, las palabras de Odette Mennesson-Rigaud, terminan con una frase que, supongo y espero, debe haber sido muy dolorosa para Leiris: « Es muy agradable, ¿verdad?, ser el etnógrafo que no está más que de paso ».

Métraux supo de la historia y era consciente, no sólo por su contacto con Verger $^{31}$, de que la revelación de los secretos del culto era una cuestión espinosa. Había redactado un texto de unas veinte páginas, muy detallado, sobre el ciclo ceremonial de iniciación en el culto y lo publicó en una revista alemana, Tribus, de corta vida y mínima difusión, para después publicarlo en Le vaudou... No hay mayores diferencias entre un texto y otro; ninguna, al menos, en lo referente

29. Para una figura tan carente de patria como Métraux (suizo, francés, naturalizado estadounidense, con largas estancias en Argentina y en Hawai, además de sus recorridos por medio mundo), ¿Haití resulta acaso una especie de patria, de hogar? En un regreso a la isla en 1948 anota: " Alegría, casi exaltación de volver a encontrarme en Haití » (Métraux 1978, p. 266).

30. Métraux, en carta a Verger, un día después de la ceremonia: « no he visto el sacrificio taurino, ya que Mme. Rigaud se ha negado a llevarme » (Métraux y Verger 1994, p. 101).

31. « [...] qué difícil es conciliar la sosegada obligación del secreto con los apetitos de publicación » (Verger a Métraux, 15/05/1953, Métraux y Verger 1994, p. 183). 
a los supuestos secretos de la etapa de enclaustramiento de los novicios, salvo una. En nota a pie de página del texto del libro el autor dice: « Las fuentes utilizadas para este capítulo están citadas en Métraux (1954-1955), « Les rites d'initiation dans le vaudou haïtien ». ¿Cuáles son esas fuentes? Además de alguna bibliografía (Milo Rigaud, Louis Maximilian), es una vez más Odette Mennesson-Rigaud, que había pasado por la iniciación, quien le había provisto de la información (Métraux 1954-1955, p. 196-197 notas 6 y 7). Métraux hace así un pase de malabarismo que le permite tres cosas al mismo tiempo: no privar a Le vaudou... de un elemento tan esencial como la descripción de los ritos de iniciación, dar al capítulo base legítima remitiendo a una publicación anterior en una revista científica y, last but not least, no inculpar a su amiga de revelar el secreto.

En fin, que Métraux no comete el error de Leiris; se ha dado cuenta, por ese incidente o por sí mismo, de que no está entre los chiriguanos o entre los pascuenses; está entre un nuevo tipo de nativo, no ya la europea Mme MennessonRigaud, sino, por ejemplo, alguien nacido en Haití, analfabeto, pero que puede llamar a su puerta en París, como Adrien Cicéron, un joven hougan proveniente de la casa de la mambo Lorgina, que había llegado a París contratado como bailarín por el ballet de Catherine Dunham (Métraux y Verger 1994, p. 151; $c f$. Leiris 1955, p. 126 y s.)

$$
* * *
$$

Obra etnológica que siendo un clásico ya no pertenece a la etnología clásica, Le vaudou haïtien envuelve una cuestión que sólo entró en foco antropológico con textos como ése y que a los Malinowski y los Evans-Pritchard no se les planteaba. Los nativos ya no son lo que eran; no son meros objetos de los que el investigador pueda desprenderse para siempre cuando los ve cada vez más pequeños mientras la lancha lo aleja de la playa. Cada vez más el otro está entre nosotros, tiene una voz que puede impugnar la nuestra; el otro nos estudia, como el reciente libro de Kopenawa y Albert (2010) hace evidente. La universalidad, si la hay, no nos tiene ya como centro. *

* Manuscrit reçu en février 2016, accepté pour publication en octobre 2016. 


\section{Referencias citadas}

BASTIDE Roger

1960, « À propos de quelques livres récents sur les Afro-Américains », Cahiers d'études africaines, 1 (4), p. 115-124.

CHARLIER-DOUCET Rachelle

2005, « Anthropologie, politique et engagement social : l'expérience du Bureau d'ethnologie d'Haïti », Gradhiva, 1 (n. s.), p. 109-126.

DASH J. Michel

2009 [1928], « Jean Price-Mars et l'image d'Haïti », in Jean Price-Mars, Ainsi parla l'oncle, Mémoire d'encrier, Québec.

DeBAene Vincent

2015, «L'Afrique fantôme ou la bifurcation », Critique, 815, p. 260-275.

DePESTRE René

1968, « Jean Price-Mars et le mythe de l'Orphée noir ou les aventures de la négritude », L'homme et la société, 7, p. 171-181.

Giobellina Brumana Fernando

2003 [1999], « La cura de la enfermedad en el campo religioso brasileño », Sentidos de la antropología/Antropología de los sentidos, Universidad de Cádiz, Cádiz, p. 115-122.

Herskovits Melville

2012 [1937], Life in a Haitian valley, Markus Wiener Pub, Princeton.

Hurbon Laënnec

1998 [1994], Los misterios del vudú, Ediciones B, Barcelona.

Hurston Zora Neale

1990 [1938], Tell my horse. Voodoo and life in Haiti and Jamaica, Perennial Library, Nueva York.

JAMIN Jean

2005, «Rendez-vous manqué avec le vodou », Gradhiva, 1 (n. s.), p. 225-231.

Kopenawa Davi y Albert Bruce

2010, La chute du ciel. Paroles d'un chaman yanomami, Plon, Paris.

LAFERRIÈRE Dany

2009 [1928], « Jean Price-Mars: un intellectuel en otage », in Jean Price-Mars, Ainsi parla l'oncle, Mémoire d'encrier, Québec.

LAURIERE Christine

2005, « D'une île à l'autre: Alfred Métraux en Haïti », Gradhiva, 1 (n. s.), p. 181-207.

LEIRIS Michel

1951, « Sacrifice d'un taureau chez le Hougan Jo Pierre-Gilles », Présence africaine, 12, p. 22-36.

1955, Fourbis, Gallimard, Paris.

1966 [1953], « Note sur l'usage de chromolithographies catholiques par les voduïsantes de Haïti », in Brisées, Gallimard, Paris, p. 176-189.

1992 [1949], « Antilles et poésie des carrefours », in Zébrage, Gallimard, Paris, p. 67-87.

1992 [1963], « Regard vers Alfred Metraux », in Brisées, Gallimard, Paris, p. 280-287. 
1996 [1934], Afrique fantôme, in Jean Jamim (org.), Miroir de l'Afrique, Gallimard, Paris.

1996 [1958], La possession et ses aspects théatraux chez les éthiopiens de Gondar, in Jean Jamim (org.), Miroir de l'Afrique, Gallimard, Paris.

MarCELIN Émile

1947, « Les grands dieux du vodou haïtien », Journal de la société des américanistes, 36 , p. 51-135.

Martino Ernesto DE

1999 [1962], La tierra del remordimiento, Bellaterra, Barcelona.

MÉTraux Alfred

1946, « The Concept of Soul in Haitian Vodu », Southwestern Journal of Anthropology, 2 (1), p. 84-92.

1947, « Introduction », in Émile Marcelin, « Les grands dieux du vodou haïtien », Journal de la société des américanistes, 36, p. 51-57.

1951, « L’Afrique vivant en Haïti », Présence africaine, 12, p. 13-21.

1953, « Réactions psychologiques à la christianisation de la vallée de Marbial (Haïti)», Revue de psychologie des peuples, 3, p. 250-267.

1954-1955, « Les rites d'initiation dans le vaudou haïtien », Tribus, 4-5, p. 177-198.

1957, Haïti. La terre, les hommes et les dieux, Éditions de la Baconnière, Neuchâtel.

1958, Le vaudou haïtien, Gallimard, Paris.

1962, « Courlander, the drum and the Hoe. Life and lore of the Haitian people » [compte rendu], L'Homme, 2 (1), p. 122-123.

1978, Itinéraires, 1. Carnets de notes et journaux de voyage (1935-1953), Payot, Paris.

Metraux Alfred y Pierre Verger

1994, Le pied à l'étrier, Éditions Jean-Michel Place, Paris.

PARENT Emmanuel

2014, " "Nothing too old, or too new for his use." Anthropologie du lore noir chez Zora Neale Hurston », Gradhiva, 19 (n. s.), p. 52-68.

POITRY Guy

1999, « Carrefour des poètes: Michel Leiris et Alfred Métraux », Bulletin du Centre genevois d'anthropologie, 5, p. 3-9.

Price-Mars Jean

2009 [1928], Ainsi parla l'oncle, Mémoire d'encrier, Quebec.

Rigaud Milo

1953, La tradition voudoo et le voudoo Haitien (son temple, ses mysteres, sa magie), Editions Niclaus, Paris.

Rigaud-MenNESSON Odette

1946, « The feasting of the gods in Haitian vodu », Primitive Man, 19 (1-2), p. 1-58.

Seabrook William

2005 [1929], La isla mágica: un viaje al corazón del vudú, Valdemar, Madrid.

VORNAX Nicolas

2005, « Vodou et production des savoirs », Anthropologie et Sociétés, 29 (3), p. 207-221. 
